\title{
Social capital, power and information sharing - evidence from the Dutch meat processing industry
}

Social capital, power and information sharing

\author{
Cees J. Gelderman, Janjaap Semeijn, Ferdi Ter Avest and Ellen Peeters \\ Department of Marketing and Supply Chain Management, \\ Open University of the Netherlands, Heerlen, Netherlands
}

\begin{abstract}
Purpose - Buying companies in the food industry increasingly recognize the need to cultivate relationships with their suppliers. Social capital and power are important to understand buyer-supplier relationships. Maintaining these relationships appears highly dependent on the degree of information sharing.

Design/methodology/approach - The study investigates how power and social capital dimensions are related to information sharing. A survey of first-tier suppliers in the Dutch meat processing industry was carried out. The data from 82 suppliers was analyzed using partial least squares.

Findings - It appears that expert power contributes to the cognitive and structural social capital. In contrast, coercive power showed no influence at all. Cognitive and structural social capital dimensions have a direct link to relational social capital, which significantly improves buyer-supplier information sharing in the food industry.

Practical implications - Buying companies can encourage supplier information sharing by building up their own expertise and cultivating social relationships. They should refrain from strong-handed practices.

Originality/value - Companies in the food and food processing industry are dependent on effective information exchange for their very survival. This study investigates the role of power and social capital in making such exchange possible and sustainable.
\end{abstract}

Keywords Information sharing, Social capital, Expert power, Coercive power, Meat processing

Paper type Research paper

\section{Introduction}

The food sector is one of the largest and most important industries worldwide. The food industry has evolved from a traditional agricultural industry into a modern high-tech industry (cf. Kähkönen and Tenkanen, 2010). As in many industries, changes urge companies to seek collaboration with a limited number of strategic suppliers (e.g. Kähkönen, 2012). Information sharing is a key component in these collaborative, interorganizational relationships (Carr and Kaynak, 2007).

Traditionally, meat processing is merely aimed at preserving meat (products) for use later and/or use elsewhere. Nowadays, meat processing is also aimed at customer satisfaction by producing meat products that are compatible with certain lifestyles and ideas on health issues (e.g. Casey et al., 2003). Meat is prone to bacterial diseases, which emphasizes the importance of hygiene and overall process quality (Mousavi et al., 2002). Companies in the

(C) Cees J. Gelderman, Janjaap Semeijn, Ferdi Ter Avest and Ellen Peeters. Published in British Food Journal. Published by Emerald Publishing Limited. This article is published under the Creative Commons Attribution (CC BY 4.0) licence. Anyone may reproduce, distribute, translate and create derivative works of this article (for both commercial and non-commercial purposes), subject to full attribution to the original publication and authors. The full terms of this licence may be seen at: http:// creativecommons.org/licences/by/4.0/legalcode.

Received 15 August 2019 
BFJ

122,11

3344

meat processing industry are faced with many rules and regulations for protecting the health of humans and animals (Tanner and Strøm-Andersen, 2019).

Information sharing in supply management has been studied for decades (for an overview, see Colicchia et al., 2019; Marshall, 2015 and Kembro et al., 2014), although to a rather limited extent in the food industry (Lusiantoro et al., 2018; Kähkönen, 2012). Despite the recognized benefits, many firms seem reluctant to share information with their supply chain partners (e.g. Olorunniwo and $\mathrm{Li}, 2010$ ). A barrier to information sharing are concerns about trust and confidentiality (e.g. Kähkönen, 2012; Li and Lin, 2006). A fear of unequal distribution of risks and returns is likely to hinder information sharing (cf. Li et al., 2014; Manatsa and McLaren, 2008). Power and dependence are generally considered important for the understanding of buyer-supplier relationships (e.g. Cox, 2001). A high dependency asymmetry may be detrimental to information sharing (cf. de Oliveira et al., 2019), while powerful companies could impose on supply chain partners which information is required (e.g. Vijayasarathy, 2010; Yigitbasioglu, 2010). Still, power is an often overlooked concept in information sharing studies.

Literature on information sharing recognizes the importance of social relations between buying and supplying companies (e.g. Li et al., 2014; Chuang et al., 2016). Social capital theory has become a useful theoretical lens for examining buyer-supplier relationships (e.g. Gelderman et al., 2016). Social capital refers to the resources that are available through networks of relationships (Nahapiet and Ghoshal, 1998). Social capital is being recognized as an important concept for examining information sharing practices (e.g. Yim and Leem, 2013). However, the impact of social capital on information sharing is hardly investigated, with Li et al. (2014) as a notable exception.

Companies in the food industry have to deal with specific issues in their supply chains, such as perishability, shelf-times, traceability, food quality and safety, seasonal behaviors, transportation and storage conditions (e.g. Eksoz, 2019; Sufiyan et al., 2019). Food companies are also faced with complex sustainability requirements (e.g. Dania et al., 2018). Although extant research has examined collaboration (cf. Dania et al., 2018) and partnerships (Eksoz et al., 2019) in food chains, scant attention has been paid to the role of social capital and power in the mechanisms that produce information sharing in the food industry. This gap constitutes the central argument for our empirical exploration, which is guided by the following main research question: what is the role of social capital and buying power in information sharing in the food industry? This study addresses three main research questions:

$R Q 1$. What is the interplay of social capital dimensions in the food industry?

$R Q 2$. What is the direct effect of (relational) social capital on information sharing in the food industry?

$R Q 3$. What is the indirect effect of buyer power on information sharing in the food industry through (cognitive and structural) social capital?

This study extends previous research on information sharing in the food industry. The originality of the study is due to the lack of knowledge on the role of power and social capital in sharing information. Drawing upon social capital theory and theory on interfirm power, we explored the interplay of power, social capital dimensions and information sharing in the Dutch meat processing industry.

\section{Literature review and hypotheses development}

2.1 Information sharing in the food sector

Information sharing refers to the exchange of critical information that facilitates interfirm collaboration among supply chain members (e.g. Zhou and Benton, 2007). Information 
sharing with supply chain members includes the exchange of information on operations management (e.g. material flow, order entry, shipping, billing) as well as the exchange of forecasts and plans (Marquez et al., 2004). A generic definition of information sharing is "the degree to which each party discloses information that may facilitate the other party's activities" (Heide and Miner, 1992, p. 275). Within the context of interfirm collaboration, information sharing refers to the exchange of data, information and/or knowledge between supply chain parties (Kembro and Näslund, 2014).

Companies in the food sector must share information for the purpose of developing valuecreating actions and activities (Kähkönen, 2012). Numerous benefits have been linked to information sharing (cf. Sahin and Robinson, 2002), even to competitive advantage (e.g. Myšková and Kuběnka, 2019; Liu et al., 2013). Shared information will lead to cost savings through inventory and batch size reductions (Marshall, 2015), improved (group) forecasts (Eksoz et al., 2019), reduced inventory levels, improved inventory control (Costantino et al., 2014) and the mitigation of the bullwhip effect and improved inventory variance (Costantino et al., 2015). Information sharing contributes to a better performance of the logistic system in terms of time, quality and speed (e.g. Hsuan et al., 2015). Collaboration and information sharing in food chains are of critical importance for companies to adequately respond to changes in a dynamic business environment (cf. Hamali et al., 2020).

Perishable products, such as meat, must be protected from the dangers of contamination, which is deemed necessary to guarantee quality, safety and availability of products (Clements et al., 2008). Products in food supply chains must be "fully traceable from farm to fork" (Eksoz et al., 2019, p. 20). Information sharing in the food industry is considered an appropriate way to reduce uncertainties (Thakur and Gunnlaugsson, 2018) and complexities in the supply chain and additionally to improve performance and decision-making (Kaipia et al., 2013; Clements et al., 2008). Kumar et al. (2020) reported a positive, significant relationship between information sharing and organizational performance in Indian agrifood supply chains.

Despite the many identified benefits of information sharing, more skeptical views point at the downsides and the limited advantages due to complexities and costs (e.g. Tran et al., 2016). Risks include a loss of power and/or competitiveness (e.g. Uzzi and Lancaster, 2003; Kähkönen, 2012; Kembr and Näslund, 2014). Kähkönen (2012) found that companies in the Finnish food industry were not always willing to openly share information, by thinking "knowledge is power" (p. 694).

Confidence in the security and quality of information systems impacts the willingness and capability of companies to share confidential information (Zhang and Li, 2006). Kataike et al. (2019) found a (strong) positive impact of relational governance on chain performance in the Uganda dairy sector. Other research in agribusiness acknowledged and confirmed that trust and relational governance are of critical importance for food supply chain performance (e.g. Mesic et al., 2018; Odongo et al., 2016). A social exchange perspective appears promising for examining information sharing practices in the supply chain (Wu et al., 2014).

\subsection{Social capital and information sharing}

Social capital theory has its roots in sociology and political science where it describes and explains the preferential treatment and cooperation between individuals and groups (e.g. Putnam, 1995). Social capital is referred to as a valuable asset that stems from access to resources made available through social relationships (Nahapiet and Ghoshal, 1998). Social capital theory has proved to be suitable for examining supply chain collaboration (Wu and Chiu, 2018) and buyer-supplier relationships (e.g. Gelderman et al., 2016). Beneficial effects of social capital on operational performance have been reported in terms of costs, quality, lead time, flexibility and delivery (e.g. Cousins et al., 2006; Lawson et al., 2008; Whipple et al., 2015). 
$\mathrm{BFJ}$ 122,11

\section{6}

Figure 1.

Social capital dimensions and information sharing
Strategic benefits include product innovation, market creation, technological development (e.g. Villena et al., 2011; Sanders, 2008; Terpend et al., 2008) and information sharing (Li et al., 2014).

Nahapiet and Ghoshal (1998) proposed three dimensions of social capital: a cognitive dimension, which represents shared meaning and understanding between actors; a relational dimension, which refers to trust, friendship, respect and mutuality established by regular interactions between actors; and a structural dimension, which refers to the frequency of interaction, the frequency of contact between the various departments in both organizations and the number of contacts between various levels within both organizations. These different dimensions can have different effects on information sharing and other performance measures (Gelderman et al., 2016; Li et al., 2014). Additionally, we assume specific interrelationships between the dimensions: cognitive social capital and structural social capital are considered antecedents of relational social capital (cf. Carey et al., 2011; Horn et al., 2014; Roden and Lawson, 2014). Figure 3 shows the interrelationships between the three social capital dimensions.

Cognitive embeddedness between two actors was found to be positively associated with relational embeddedness, in that alignment between beliefs and expectations reinforces trust and commitment (Simsek et al., 2003). Cognitive social capital, as shared understandings, values and beliefs, is likely to breed trust (Carey et al., 2011). If parties have little understanding for one another, relational capital is not likely to grow. With Roden and Lawson (2014), we expect that cognitive social capital has a positive impact on relational social capital. In addition, we propose a positive relationship between structural capital and relational capital as well. Structural social capital, as social interactions, facilitates the development of trusting relationships (e.g. Carey et al., 2011). Studies have shown that trust is developed through direct experiences and interactions with each other (e.g. Granovetter, 1985). Therefore, we propose:

\section{H1. Cognitive social capital has a positive impact on relational social capital.}

H2. Structural social capital has a positive impact on relational social capital.

Although the concept of information sharing has received increasing attention in academic literature, few empirical studies investigate the relationship between (dimensions of) social capital and information sharing. Li et al. (2014) show that cognitive social capital and relational social capital have a positive impact on information sharing. In another study, it was found that structural social capital, relational social capital and cognitive social capital affect knowledge sharing, which in turn influenced organizational performance (Kim et al., 2013). Carlos and Pinho (2013) reported that trusted parties showed reduced feelings of vulnerability and as a result, they did not hesitate in committing and cooperating in a longterm relationship. In their study on Chinese food supply chains, Fu et al. (2017) found a significant effect of trust and commitment on information sharing. Obviously, with a lack of trust, parties will be unwilling to exchange sensitive information (e.g. Fawcett et al., 2007). (see Figure 1) We expect:

H3. Relational social capital has a positive impact on information sharing.

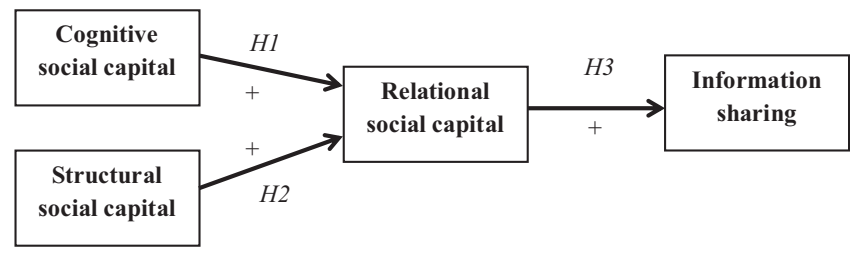




\subsection{The influence of coercive and expert power}

Considering the importance of social capital in buyer-supplier relationships, we need a thorough understanding of its drivers and barriers. However, little work has been done to explore the antecedents of social capital (cf. Chang and Hsu, 2016). In addition, the few studies on these antecedents focus on social capital on an individual level within organizations. An example is Van den Hooff and Huysman (2009), who investigated the impact of organizational characteristics (e.g. organizational culture and structure) on social capital and knowledge sharing with colleagues. The actual sharing of information by a weaker party is likely to be influenced by the power of the stronger party. In many industries, buying firms are able to dominate or even exploit their suppliers (Yigitbasioglu, 2010; Schleper et al., 2017). Large retail organizations initiate decisions, configure products and place orders that pull products through the supply chain (Hsuan et al., 2015). Therefore, customers and buyers are usually more powerful than the manufacturers and suppliers of goods (Huo et al., 2016). Suppliers may be reluctant to share information due to perceived risks, costs and other downsides (e.g. Tran et al., 2016; Uzzi and Lancaster, 2003: Kembro and Näslund, 2014).

A dominant player can force weaker parties to share information. The use of power and influence is considered effective in mobilizing suppliers into knowledge and information sharing (Grant and Preston, 2019). Buyers can use influence strategies in achieving compliance and cooperation from suppliers (e.g. Frazier and Rody, 1991). Another mechanism might be that dominated suppliers will try to withhold confidential and important information (Kembro et al., 2017). In a more positive vein, some studies found that power can provide an effective coordination of exchange relationships, promoting supply chain integration and performance (e.g. Maloni and Benton, 2000; Caniëls and Gelderman, 2010). How can we account for these paradoxical different effects?

The answer could be found in the multidimensional nature of power. Different types of power may have different effects (Maloni and Benton, 2000; Grant and Preston, 2019). Dominant firms can have different power bases to influence a weaker party (French and Raven, 1959). Power types can be classified by their need for activation. Activated power types are based on intentional use, while passive power types are created by the perceptions of the other party and are hard to control directly (Reimann and Ketchen, 2017).

Coercive power is a form of activated power. Coercive power includes promising rewards in case of compliance and threatening punishments in case of noncompliance (Gelderman et al., 2008; Benton and Maloni, 2005). This type of power use is based on the willingness to inflict negative consequences to noncompliance (Gundlach and Cadotte, 1994). Expert power is a typical example of a passive power type. Expert power is based on the appreciation of the other party's expertise (Benton and Maloni, 2005). Passive power types are likely to have beneficial effects on relationships, while activated power types can have detrimental effects (Huo et al., 2017). For instance, the threat or actual use of expert power in a supply chain increases cognitive social capital in terms of common interests as well as promoting collective goals and vision (Jonsson and Zineldin, 2003). The opposite is expected from the threat or actual use of coercive power Chen et al., (2015). We propose the following hypotheses:

H4. Coercive power has a negative impact on cognitive (a) and structural social capital (b).

H5. Expert power has a positive impact on cognitive (a) and structural social capital (b). Figure 2 shows the conceptual model and the proposed hypotheses.

\section{Research method}

The meat processing industry is a subsector in the (global) meat industry, which produces far over 300m tons of meat worldwide (Lynn, 2017). The Dutch meat processing industry
Social capital, power and information sharing

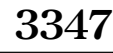


$\mathrm{BFJ}$

122,11

3348

comprises a small number of large concerns doing business worldwide and a larger number of smaller, specialist companies with a more regional focus. The three leading meat processing companies in the Netherlands are the VION Food Group, Campofrio and Zwanenberg Food Groups. In 2017, the revenue of the VION Food Group was approximately $\$ 6$ bn, Campofrio's revenue amounted to $\$ 2.28 \mathrm{bn}$, while Zwanenberg Food Group was the third in line with a revenue of $\$ 0.46 \mathrm{bn}$ in 2017 (Van de Pas, 2019). More than 650 companies are engaged in the production, processing and preserving of meat products in the Netherlands in 2018 (www.statista.com/statistics/715532/).

Data collection took place through an electronic survey among a sample of managers employed at European food producing companies. An electronic survey shows similar reliability for email surveys compared to online surveys (e.g. Deutskens et al., 2006). To test the hypotheses, we invited suppliers of Zwanenberg Food Group to participate in the study. The Zwanenberg Food Group is one of the leading European producers and exporters of meat products and canned meat. Suppliers were selected on two criteria. The organization should be Dutch and it has to be a first-tier supplier for Zwanenberg Food Group. A draft version of the questionnaire was pretested on a small number of respondents (pilot study). The final version of the questionnaire was administered online.

A total number of 157 suppliers were first contacted by email, then the questionnaire was sent out electronically. After a follow-up email, sent after two weeks, a total number of 82 questionnaires were completed, which results in an effective response rate of 52,3\% (82/157). We included some background variables to get insight in sample characteristics. Table 1 shows the responses for the background variables. Company size was measured by questions about the number of employees and annual revenues in Euros. About $11 \%$ of the respondents were employed by companies with annual revenues less than $€ 10 \mathrm{~m}$, while $39 \%$ worked at larger companies with more than $€ 100 \mathrm{~m}$ revenues. The majority of companies contracted fewer than 100 suppliers (64\%) and employed fewer than 500 employees (66\%). Respondents were asked to indicate their job title that reflects the position in their company. About $17 \%$ of the sample consisted of managing directors. Almost 59\% held a position in sales (mostly account managers), while $24 \%$ was employed in another position. All respondents were involved in activities and decisions regarding the customer relationship management of their company, which suggests sufficient knowledge from the respondents to complete the questionnaire.

To investigate the constructs, six variables were measured on seven-point Likert scales. These variables are information sharing, cognitive social capital, relational social capital, structural social capital, coercive power and expert power. To ensure that the respondent will take the time to read the questions carefully, there are questions with both positive and negative pronunciations, which is important for the validity of questions measured by a seven-point Likert scale. The questions were translated into Dutch. Two translators executed

Figure 2.

Conceptual model

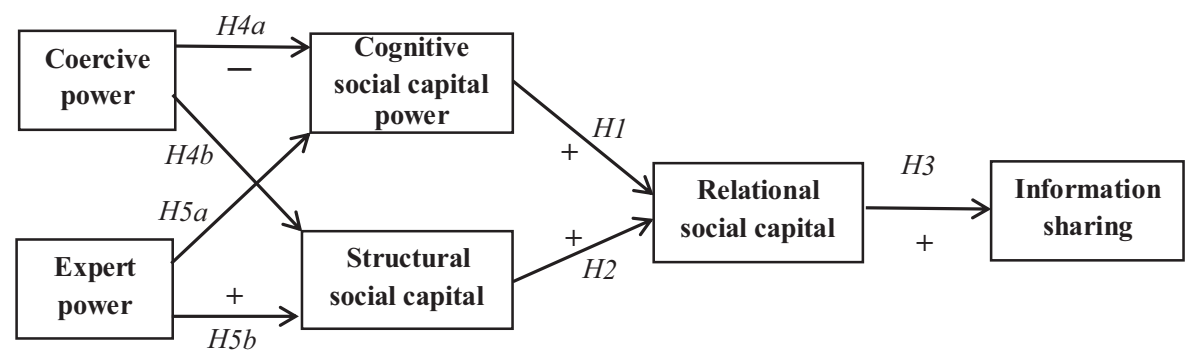


the translation, one is a native speaker of the source language and one is a native speaker of the target language.

All operationalizations were derived from measurement scales used and validated in other academic studies and adapted to fit the context of this study. Coercive power was measured by using the four items adapted from Brown et al. (1995). An example item is: "The major customer's personnel would somehow get back at us if we do not make changes in our research and development." Expert power was measured by four items adapted from Brown et al. (1995). An example item is: "Our major customer ensures changes in our research and development because we trust the customer's judgment." It should be noted that the operationalizations of the power constructs refer to the threat that emanates from the actual use of power. It is not about the actual use of power, but the imminent possibility that buyer power is exercised at the expensive of a supplier. Structural social capital was measured by three items derived from Villena et al. (2011). An example item is: "Our major customer and we do not have frequent and intensive interaction with each other" (reverse coded). Cognitive social capital was measured by four items derived from Li et al. (2014) and Son et al. (2016). An example item is: "Our major customer and we share the same vision." Relational social capital was measured by five items derived from Li et al. (2014) and Wu et al. (2014) and Villena et al. (2011). An example item is: "Our major customer and we are concerned about the welfare or interests of each other when making important decisions." Information sharing was measured by four items derived from Li et al. (2014) and Wu et al. (2014). An example item is:

\begin{tabular}{|c|c|c|c|c|}
\hline Variable & Description & Frequency & $\%$ & \\
\hline \multirow[t]{3}{*}{ Type of industry } & Traditional manufacturing & 54 & 65.9 & \\
\hline & Service & 15 & 18.3 & \\
\hline & High-tech manufacturing & 13 & 15.9 & \\
\hline \multirow[t]{4}{*}{ Age of the organization } & $<5 y$ & 2 & 2.4 & \\
\hline & $+5-10 y$ & 3 & 3.7 & \\
\hline & $+10-20$ & 8 & 9.8 & \\
\hline & $>20 y$ & 69 & 84.1 & \\
\hline \multirow[t]{4}{*}{ Number of employees } & $<500$ & 54 & 65.9 & \\
\hline & $+500-1,000$ & 12 & 14.6 & \\
\hline & $+1,000-5,000$ & 11 & 13.4 & \\
\hline & $>5,000$ & 5 & 6.1 & \\
\hline \multirow[t]{4}{*}{ Annual revenue } & $<10.000 .000 €$ & 9 & 11 & \\
\hline & $+10.000 \mathrm{k}-50.000 \mathrm{k}$ & 26 & 31.7 & \\
\hline & $+50.000 \mathrm{k}-100.000 \mathrm{k}$ & 15 & 18.3 & \\
\hline & $>100.000 \mathrm{k}$ & 32 & 39 & \\
\hline \multirow[t]{4}{*}{ Number of suppliers } & $<100$ & 53 & 64.6 & \\
\hline & $+100-300$ & 17 & 20.7 & \\
\hline & $+300-500$ & 3 & 3.7 & \\
\hline & $>500$ & 9 & 11 & \\
\hline \multirow[t]{4}{*}{ Number of customers } & $<100$ & 17 & 20.7 & \\
\hline & $+100-300$ & 23 & 28 & \\
\hline & $+300-500$ & 8 & 9.8 & \\
\hline & $>500$ & 34 & 41.5 & \\
\hline \multirow[t]{7}{*}{ Job title/position } & Account manager & 44 & 53.7 & \\
\hline & Product manager & 2 & 2.4 & \\
\hline & Financial worker & 2 & 2.4 & \\
\hline & Buyer & 3 & 3.7 & \\
\hline & Customer service empl & 1 & 1.2 & \\
\hline & Managing dir & 14 & 17.1 & Table 1. \\
\hline & Other & 16 & 19.5 & Sample properties \\
\hline
\end{tabular}

Social capital, power and information sharing

3349 
$\mathrm{BFJ}$ 122,11

\section{0}

Table 2.

AVE and correlations between constructs
"We are willing to share our actual sales data with our major customer." The appendix shows the items that have been used for the construction and the measurement of the variables. In order to warrant discriminant and convergent validity next to construct reliability, we examined the measurement model by evaluating loadings, average variance extracted (AVE) and composite reliability (CR). The AVE scores and the correlations between the variables are included in Table 2.

Partial least squares (PLS) analyses were performed to test the structural model using the plspm package in $R$ (Sanchez et al., 2017). The variance-based PLS-SEM approach achieves relatively high statistical power even with small sample sizes and is the recommended method when working with reflective constructs (Hair et al., 2017). In line with suggestions made by Davies (2001) with regard to uncertainty and bias avoidance when performing PLS, we compared the results of a more parsimonious model (i.e. less parameters) leaving nonsignificant results out.

\section{Results}

The statistical analyses comprise two main steps: (1) in the first step, the "outer" model is tested, and (2) in the second step, the "inner" model is tested. The outer model maps the indicators on the latent factors and examines indicator loadings, which analyzes the measurement model and thus reliability and validity. The inner model maps the paths between the latent factors, which analyzes the structural or hypothesized model. Eigenvalues did not indicate multidimensionality of any latent factor and Cronbach's alpha values are all well above the threshold values of 0.60 (Hair et al., 2014). All AVE values are well above 0.40. The loadings of the indicators on the latent factors are all well above 0.40 and there were no cross-loadings on other factors. In sum, results indicate unidimensionality of the latent factors and suggest that convergent and discriminant validity of each latent factor is acceptable and show evidence for the reliability of the constructs.

The results of the inner model are presented in Table 3. Five of the seven hypothesized paths are statistically significant. The results confirm the substructure of the social capital dimensions ( $\mathrm{H} 1$ and $\mathrm{H} 2$ ). We also found support for the impact of relational structural social capital (H3). However, no statistical support was found for the hypotheses that assumed a relationship between coercive power and cognitive social capital (H4a) and structural social capital (H4b). It appears that expert power, as expected, has a positive impact on these two social capital dimensions (H5a and H5b). Results did not differ with a more parsimonious path model leaving nonsignificant paths out. Figure 3 shows the structural model including the size and significance of path coefficients, as well as $R^{2}$ values.

\section{Conclusions and discussion}

Information sharing is of critical importance in the food industry for reasons of visibility, traceability, quality and safety of food products (cf. Fu et al., 2017). Information sharing has

\begin{tabular}{lcrrrrr}
\hline Constructs & AVE & 1 & 2 & 3 & 4 & 5 \\
\hline 1. Coercive Power & 0.470 & & & & & \\
2. Expert Power & 0.585 & -0.352 & & & & \\
3. Cognitive Social Capital & 0.460 & -0.223 & 0.424 & & & \\
4. Structural Social Capital & 0.649 & -0.101 & 0.402 & 0.096 & & \\
5. Relational Social Capital & 0.416 & 0.071 & 0.114 & 0.327 & 0.245 & \\
6. Information Sharing & 0.421 & 0.043 & 0.181 & 0.331 & 0.208 & 0.248 \\
\hline
\end{tabular}




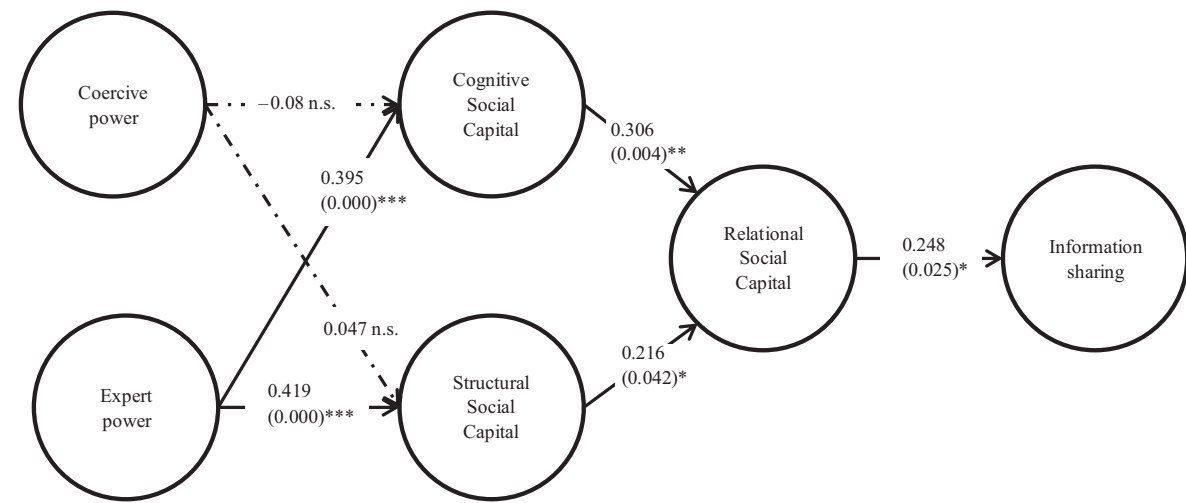

Note(s): Path coefficientsand significance levels added on the arrows. Dotted arrows indicate non significance

$n . s .=$ not significant; ${ }^{*} p \leq 0.050 ; * * p \leq 0.010 ; * * * p \leq 0.001$
Social capital, power and information sharing

\section{1}

Figure 3.

PLS results of the structural model

been extensively studied within the context of industrial buyer-supplier relationships, but to a limited extent within the food industry. The context of perishability of products has an unclear impact on information sharing within the food industry (cf. Lusiantoro et al., 2018). Literature recognizes the importance of social capital that accrues in buyer-supplier relationships. However, no studies have investigated the role of the substructure of the three social capital dimensions on information sharing in the food industry. Despite the many attributed benefits, many firms seem reluctant to share important information with their supply chain partners (e.g. Kähkönen, 2012). A high dependence asymmetry is likely to be important in the food industry (e.g. de Oliveira et al., 2019), although many studies seem to have overlooked the role of power in information sharing. This study was aimed at filling these gaps by investigating the interplay of power, different social capital dimensions and information sharing within the food sector.

This study contributes to the body of knowledge about information sharing in buyersupplier relationships in the food industry. Only few studies on information sharing are set in the food industry ( $\mathrm{Fu}$ et al., 2017). First, our study extends previous literature by investigating the influence of the substructure of social capital dimensions on information sharing. The results of our study confirm the theoretically based substructure of the three social capital dimensions (cf. Gelderman et al., 2016; Horn et al., 2014; Carey et al., 2011). Indeed, cognitive capital (shared meaning and understanding) and structural capital

\begin{tabular}{lcccc}
\hline Path & Path coefficients & t-Values & Sign. Levels & $p$-Values \\
\hline Coercive Power $\rightarrow$ Cognitive Social Capital & -0.084 & -0.774 & N.S. & 0.441 \\
Coercive Power $\rightarrow$ Structural Social Capital & 0.047 & 0.426 & N.S. & 0.671 \\
Expert Power $\rightarrow$ Cognitive Social Capital & 0.395 & 3.640 & $* * *$ & 0.000 \\
Expert Power $\rightarrow$ Structural Social Capital & 0.419 & 3.810 & $* * *$ & 0.000 \\
Cognitive Social Capital $\rightarrow$ Relational Social Capital & 0.306 & 2.940 & $* *$ & 0.004 \\
Structural Social Capital $\rightarrow$ Relational Social Capital & 0.216 & 2.070 & $*$ & 0.042 \\
Relational Social Capital $\rightarrow$ Information Sharing & 0.248 & 2.290 & $*$ & 0.025
\end{tabular}

Note(s): N.S. $=$ not significant; $* p \leq 0.050 ; * * p \leq 0.010 ; * * x \leq 0.001$

Table 3.

Size and significance of the structural model path coefficients 
$\mathrm{BFJ}$

122,11

3352

(interactions and contacts) are antecedents of relational social capital (trust, friendship, mutuality). In addition, the empirical findings support the hypothesis that links relational social capital to information sharing (cf. Li and Lin, 2006; Fawcett et al., 2007; Wang et al., 2014).

Second, although power is generally considered a key concept in understanding buyerpower relationships, dependence asymmetry appears to be an overlooked factor in information sharing studies. This study included the role of coercive and expert power for gaining additional insights in information sharing. Third, literature shows a rather inconclusive picture of the impact of power on coordination, collaborating and information sharing in supply chains. Some studies assume a direct effect of power on information sharing (e.g. Li et al., 2014; Yigitbasioglu, 2010). In this study we have argued that power will only indirectly influence information sharing, namely through social capital. We found partial evidence for this mechanism.

Fourth, we did find a (positive) path that runs from expert power through social capital to information sharing. Suppliers in the meat processing industry appreciate the expertise of the buyer, which contributes to the shared understanding (cognitive capital) and interactions (structural capital). However, the provision of information might not be completely mandatory. Suppliers could be forced to exchange information by the use of coercive buyer power. For this power type, we expected a negative impact on social capital, which works on to information sharing. Companies are known to be reluctant to share information, most likely when they feel that disclosure of information is a loss of power (cf. Croom et al., 2000). However, we did not find a statistically significant effect of coercive power on social capital. This finding is in line with the notion by some that the use of power is not always problematic and can be a positive force in supply chains, as long as the dominant party acts fairly (cf. Yigitbasioglu, 2010) and does not necessarily exploit the weaker party (cf. Pfeffer and Salancik, 1978; Caniëls and Gelderman, 2010). By distinguishing coercive and expert power, as contrasting power types, we have shed light on the complex role that power can play in information sharing between buyers and suppliers.

Also, we found a (relatively strong) negative correlation between coercive power and expert power. Apparently, these power types were employed as substitutes and not in a complementary way. In other words, a buyer that uses expert power in a supplier relation is not likely to simultaneously use coercive power as well (and vice versa).

\section{Limitations and recommendations}

This study has a number of limitations, which could induce further research. The sample was restricted to supplying companies of one buying (food producing) company. The sample method therefore imposes restrictions on the generalizability of our findings. The study could be replicated in other settings, for instance, by selecting other subsectors in the food industry or by focusing on (innovative) start-ups. Like most studies, we examined the information sharing by suppliers. A promising line of research could be to study the effect of backward information sharing, from buying companies to supply companies (cf. Han et al., 2019). To get more insights into the effects of power and social capital, future research could use a dyadic or a network approach and include the experience and views of multiple buyers and suppliers. Complex and potentially rich research designs could include multiple layers of supply chains (Colicchia et al., 2019). Another limiting aspect is the cross-sectional nature of this study. Experimental and longitudinal studies would be more suitable for investigating cause-effect relationships, shedding light on the interplay of the various variables under study. Case study research could be aimed at more thoroughly investigating the relationship with these concepts. As in many studies, our questionnaire was completed by employees, representing 
their company. A promising avenue for future research could be to investigate the interplay of the individual level and the firm level.

Studies have argued the need for advanced information technology to exchange supply chain information (e.g. Li et al., 2014). Poor data quality and a lack of shared information will result in costly repercussions and operational problems (Tran et al., 2016). Future studies could focus on the content and the quality of information shared among supply chain partners (cf. Jie and Gengatharen, 2019; Li et al., 2014). To be more specific, research could differentiate between operational, tactical and strategic information (cf. Wu et al., 2014). Especially in the food industry, with perishable product chains (Lusiantoro et al., 2018), certain information types are more important than others. Another promising avenue for future research is investigating the role and the impact of information sharing on (environmental and social) sustainability in food supply chains (Dania et al., 2018; Ahmed et al., 2018).

We investigated power and social capital on information sharing in the food industry. We drew upon social capital theory and theory on interfirm power for our hypotheses and conceptual model. Obviously, other theoretical lenses could be used for information sharing studies. Game theory and stakeholder theory are examples of alternative theoretical foundations for investigating buyer-supplier relationships, but also for examining the roles of other stakeholders such as competitors, consumers and governments.

The findings of our study have also practical relevance. Applications may be in the field of business advice, consultancy and therefore training. Companies in the food industry need reliable information from their suppliers, although many firms seem reluctant to share information. The results of our study show that investing in relational social capital contributes to the willingness of suppliers to share information. An atmosphere of trust, respect and caring about each other promotes information sharing. Buying companies should acknowledge that relational social capital (trust, respect, friendship) can be promoted by investing in cognitive social capital (shared understanding and meaning) and structural social capital (frequency of contacts and interactions).

Other practical recommendations concern the use of buying power. The use of coercive power showed no influence at all (nor positive, nor negative) in our study. Eager purchasing professional in the food industry might be tempted to put the pressure on their suppliers. However, whenever information sharing is an important performance measure, the idea of punishing and rewarding suppliers is likely to be ineffective. Purchasing professionals should refrain from coercive power, from the perspective of collaboration and information sharing.

The results of our study suggest that purchasing professionals could benefit from the finding that expert power impacts information sharing, be it in an indirect way through high levels of social capital. Social networks and social relation factors do play an important intermediate role in the food sector. Trust is essential for suppliers to exchange information with a more powerful customer. Sharing operational information on production and deliveries forms a very different context compared to sharing strategic information for gaining competitive value, promoting collaborative behaviors between various supply chain members. Companies in the food industry can encourage supplier information sharing by building up their own expertise and cultivating social relationships.

\section{References}

Ahmed, S., Khan, A., Paul, S. and Kazmi, S.H.A. (2018), "Role of green information system and information cycle in environmental performance", International Conference on Management Science and Engineering Management. Springer, Cham, chapter 17, pp. 465-476.

Benton, W. and Maloni, M. (2005), "Trustworthiness as a source of competitive advantage", Strategic Management, Vol. 23 No. 1, pp. 1-22. 
BFJ 122,11

Brown, J., Lusch, R. and Nicholson, C. (1995), "Power and relationship commitment: their impact on marketing channel member performance", Journal of Retailing, Vol. 71 No. 4, pp. 363-392.

Caniëls, M.C.J. and Gelderman, C.J. (2010), "The safeguarding effect of governance mechanisms in inter-firm exchange: the decisive role of mutual opportunism", The British Journal of Management, Vol. 21 No. 1, pp. 239-254.

Carey, S., Lawson, B. and Krause, D. (2011), "Social capital configuration, legal bonds and performance in buyer-supplier relationships", Journal of Operations Management, Vol. 29 No. 4, pp. 277-288.

Carlos, J. and Pinho, M. (2013), "The role of relational social capital in examining exporterintermediary relationships", European Business Review, Vol. 25 No. 6, pp. 553-570.

Carr, A. and Kaynak, H. (2007), "Communication methods, information sharing, supplier development and performance", International Journal of Operations and Production Management, Vol. 27 No. 4, pp. 346-370.

Casey, N.H., Niekerk, W.A. and Webb, E.C. (2003), "Goat meat”, in Caballero, B. (Ed.), Encyclopedia of Food Sciences and Nutrition, Academic Press, Cambridge, Massachusetts, pp. 2937-2944.

Chang, C. and Hsu, M. (2016), "Understanding the determinants of users' subjective well-being in social networking sites: an integration of social capital theory and social presence theory", Behaviour and Information Technology, Vol. 35 No. 9, pp. 720-729.

Chen, J., Zhao, X., Lewis, M. and Squire, B. (2015), "A multi-method investigation of buyer power and supplier motivation to share knowledge", Production and Operations Management, Vol. 25 No. 3, pp. 1-15.

Chuang, M., Chen, C. and Lin, M. (2016), "The impact of social capital on competitive advantage", Management Decision, Vol. 54 No. 6, pp. 1443-1463.

Clements, M.D., Lazo, R.M. and Martin, S.K. (2008), "Relationship connectors in NZ fresh produce supply chains", British Food Journal, Vol. 110 Nos 4-5, pp. 346-360.

Colicchia, C., Creazza, A., Noè, C. and Strozzi, F. (2019), "Information sharing in supply chains: a review of risks and opportunities using the systematic literature network analysis (SLNA)", Supply Chain Management: An International Journal, Vol. 24 No. 1, pp. 5-21.

Costantino, F., Di Gravio, G., Shaban, A. and Tronci, M. (2014), "The impact of information sharing and inventory control coordination on supply chain performances", Computers and Industrial Engineering, Vol. 76, pp. 292-306.

Costantino, F., Di Gravio, G., Shaban, A. and Tronci, M. (2015), "The impact of information sharing on ordering policies to improve supply chain performances", Computers and Industrial Engineering, Vol. 82, pp. 127-142.

Cousins, P.D., Handfield, R.B. and Lawson, B. (2006), "Creating supply chain relational capital: the impact of formal and informal socialization processes", Journal of Operations Management, Vol. 24 No. 6, pp. 851-863.

Cox, A. (2001), "Understanding buyer and supplier power: a framework for procurement and supply competence", Journal of Supply Chain Management, Vol. 37 No. 2, pp. 8-15.

Croom, S., Romano, P. and Giannakis, M. (2000), "Supply chain management: an analytical framework for critical literature review", European Journal of Purchasing and Supply Management, Vol. 6 No. 1, pp. 67-83.

Dania, W.A.P., Xing, K. and Amer, Y. (2018), "Collaboration behavioural factors for sustainable agrifood supply chains: a systematic review", Journal of Cleaner Production, Vol. 186, pp. 851-864.

Davies, A.M.C. (2001), "Uncertainty testing in PLS regression”, Spectroscopy Europe, Vol. 13 No. 6, pp. 16-19.

de Oliveira, G.M., da Cunha, C.F., Caleman, S.M.D.Q. and Maia, R.L.G. (2019), "Information asymmetry: the case of cattle supply transaction in Brazil”, British Food Journal, Vol. 121 No. 8, pp. 1825-1837.

Deutskens, E., de Ruyter, K. and Wetzels, M. (2006), "An assessment of equivalence between online and mail surveys in service research", Journal of Service Research, Vol. 8 No. 4, pp. 346-355. 
Eksoz, C., Mansouri, S.A., Bourlakis, M. and Önkal, D. (2019), "Judgmental adjustments through supply integration for strategic partnerships in food chains", Omega, Vol. 87, pp. 20-33.

Fawcett, S.E., Osterhaus, P., Magnan, G.M., Brau, J.C. and McCarter, M.W. (2007), "Information sharing and supply chain performance: the role of connectivity and willingness", Supply Chain Management: An International Journal, Vol. 12 No. 5, pp. 358-368.

Frazier, G. and Rody, C. (1991), "The Use of influence strategies in interfirm relationships in industrial product channels", Journal of Marketing, Vol. 55 No. 1, pp. 1-52.

French, R. and Raven, B. (1959), "The bases of social power", in Cartwright, D. (Ed.), Studies in Social Power, University of Michigan Press, Michigan, pp. 155-164.

Fu, S., Han, Z. and Huo, B. (2017), "Relational enablers of information sharing: evidence from Chinese food supply chains", Industrial Management and Data Systems, Vol. 117 No. 5, pp. 838-852.

Gelderman, C.J., Semeijn, J. and de Zoete, R. (2008), "The use of coercive influence strategies by dominant suppliers", Journal of Purchasing and Supply Management, Vol. 14 No. 4, pp. 220-229.

Gelderman, C.J., Semeijn, J. and Mertschuweit, P.P. (2016), "The impact of social capital and technological uncertainty on strategic performance: the supplier perspective", Journal of Purchasing and Supply Management, Vol. 22 No. 3, pp. 225-234.

Granovetter, M.S. (1985), "Economic action and social structure: the problem of embeddedness", American Journal of Sociology, Vol. 91 No. 3, pp. 481-510.

Grant, S.B. and Preston, T.A. (2019), "Using social power and influence to mobilise the supply chain into knowledge sharing: a case in insurance", Information and Management, Vol. 56 No. 5 , pp. $625-639$.

Gundlach, G.T. and Cadotte, E.R. (1994), "Exchange interdependence and interfirm interaction: research in a simulated channel setting", Journal of Marketing Research, Vol. 31 No. 4, pp. 516-532.

Hair, J., Sarstedt, M., Hopkins, L. and Kuppelweiser, V. (2014), "Partial least squares structural equation modeling (PLS-SEM) - an emerging tool in business research", European Business Review, Vol. 26 No. 2, pp. 106-121.

Hair, J.F., Hult, G.T.M., Ringle, C.M. and Sarstedt, M. (2017), A Primer on Partial Least Squares Structural Equation Modeling (PLS-SEM), 2nd ed., Sage, Thousand Oaks, CA.

Hamali, S., Prihandoko, D., Kurniawan, S. and Ramdhani, R. (2020), "The effects of supply chain information integration on organizational performance in food small industry", Management Science Letters, Vol. 10 No. 3, pp. 695-702.

Han, Z., Huo, B. and Zhao, X. (2019), "Backward supply chain information sharing: who does it benefit?", Supply Chain Management: An International Journal, Vol. ahead-of-print. No. aheadof-print. doi: 10.1108/SCM-03-2019-0098.

Heide, J. and Miner, A. (1992), "The shadow of the future: effects of anticipated interaction and frequency of contact on buyer-seller cooperation", Academy of Management Journal, Vol. 35 No. 2, pp. 265-291.

Horn, P., Scheffler, P. and Schiele, H. (2014), "Internal integration as a pre-condition for external integration in global sourcing: a social capital perspective", International Journal of Production Economics, Vol. 153, pp. 54-65.

Hsuan, J., Skjøtt-Larsen, T., Kinra, A. and Kotzab, H. (2015), Managing the Global Supply Chain, 4th ed., Copenhagen Business Press, Frederiksberg.

Huo, B., Wang, Q., Zhao, X. and Schuh, S. (2016), "Threats and benefits of power discrepancies between organizations: a supply chain perspective", International Journal of Production Research, Vol. 54 No. 13, pp. 3870-3884.

Huo, B., Flynn, B.B. and Zhao, X. (2017), "Supply chain power configurations and their relationship with performance", Journal of Supply Chain Management, Vol. 53 No. 2, pp. 88-111.
Social capital, power and information sharing 
BFJ 122,11

Jie, F. and Gengatharen, D. (2019), "Australian food retail supply chain analysis", Business Process Management Journal, Vol. 25 No. 2, pp. 271-287.

Jonsson, P. and Zineldin, M. (2003), "Achieving high satisfaction in supplier-dealer working relationships", Supply Chain Management: An International Journal, Vol. 8 No. 3, pp. 224-240.

Kähkönen, A.K. (2012), "Value net-a new business model for the food industry?”, British Food Journal, Vol. 114 No. 5, pp. 681-701.

Kähkönen, A.K. and Tenkanen, M. (2010), "The impact of power on information sharing in the Finnish food industry”, British Food Journal, Vol. 112 No. 8, pp. 821-835.

Kaipia, R., Dukovska-Popovska, I. and Loikkanen, L. (2013), "Creating sustainable fresh food supply chains through waste reduction", International Journal of Physical Distribution and Logistics Management, Vol. 43 No. 3, pp. 262-276.

Kataike, J., Molnar, A., De Steur, H. and Gellynck, X. (2019), "Examining the relationship between chain governance structures and chain performance", British Food Journal, Vol. 121 No. 8, pp. $1850-1870$.

Kembro, J. and Näslund, D. (2014), "Information sharing in supply chains, myth or reality? A critical analysis of empirical literature", International Journal of Physical Distribution and Logistics Management, Vol. 44 No. 3, pp. 179-200.

Kembro, J., Selviaridis, K. and Näslund, D. (2014), "Theoretical perspectives on information sharing in supply chains: a systematic literature review and conceptual framework", Supply Chain Management: An International Journal, Vol. 19 Nos 5-6, pp. 609-625.

Kembro, J., Näslund, D. and Olhager, J. (2017), "Information across multiple supply chain tiers: a Delphi study on antecedents", International Journal of Production Economics, Vol. 193, pp. 77-86.

Kim, T., Lee, G., Soyon, P. and Seunggil, L. (2013), "Social capital, knowledge sharing and organizational performance: what structural relationship do they have in hotels?", International Journal of Contemporary Hospitality Management, Vol. 25 No. 5, pp. 683-704.

Kumar, A., Singh, R.K. and Modgil, S. (2020), "Exploring the relationship between ICT, SCM practices and organizational performance in agri-food supply chain", Benchmarking: An International Journal, Vol. 27 No. 3, pp. 1003-1041.

Lawson, B., Tyler, B.B. and Cousins, P.D. (2008), "Antecedents and consequences of social capital on buyer performance improvement", Journal of Operations Management, Vol. 26 No. 3, pp. $446-460$.

Li, Y. and Lin, B. (2006), "Accessing information sharing and information quality in supply chain management”, Decision Support Systems, Vol. 42 No. 3, pp. 1641-1656.

Li, Y., Ye, F. and Sheu, C. (2014), "Social capital, information sharing and performance - evidence from China", Journal of Operations and Production Management, Vol. 34 No. 11, pp. 1440-1462.

Liu, H., Ke, W., Wei, K. and Hua, Z. (2013), "Effects of supply chain integration and market orientation on firm performance: evidence from China", International Journal of Operations and Production Management, Vol. 33 No. 3, pp. 322-346.

Lusiantoro, L., Yates, N., Mena, C. and Varga, L. (2018), "A refined framework of information sharing in perishable product supply chains", International Journal of Physical Distribution and Logistics Management, Vol. 48 No. 3, pp. 254-283.

Lynn, J. (2017), All about the Meat Processing Industry, available at: https://www.worldatlas.com (accessed 27 March 2018).

Maloni, M. and Benton, W.C. (2000), "Power influences in the supply chain", Journal of Business Logistics, Vol. 21 No. 1, pp. 49-73.

Manatsa, P.R. and McLaren, T.S. (2008), "Information sharing in a supply chain: using agency theory to guide the design of incentives", Supply Chain Forum: An International Journal, Vol. 9 No. 1, pp. 18-26. 
Marquez, A.C., Bianchi, C. and Gupta, J.N.D. (2004), "Operational and financial effectiveness of -collaboration tools in supply chain integration”, European Journal of Operational Research, Vol. 159 No. 2, pp. 348-363.

Marshall, D.A. (2015), "Assessing the value of supply chain information sharing in the new millennium”, International Journal of Supply Chain Management, Vol. 4 No. 4, pp. 10-21.

Social capital, power and information sharing

Mesic, Ž., Molnár, A. and Cerjak, M. (2018), "Assessment of traditional food supply chain performance using triadic approach: the role of relationships quality", Supply Chain Management: An International Journal, Vol. 23 No. 5, pp. 396-411.

Mousavi, A., Sarhadi, M., Lenk, A. and Fawcett, S. (2002), "Tracking and traceability in the meat processing industry: a solution", British Food Journal, Vol. 104 No. 1, pp. 7-19.

Myšková, R. and Kuběnka, M. (2019), "Information sharing in the context of business cooperation-as a source of competitive advantage", Journal of International Studies, Vol. 12 No. 3, pp. 169-182.

Nahapiet, J. and Ghoshal, S. (1998), "Social capital, intellectual capital and the organizational advantage", The Academy of Management Review, Vol. 23 No. 2, pp. 242-266.

Odongo, W., Dora, M., Molnar, A., Ongeng, D. and Gellynck, X. (2016), "Performance perceptions among food supply chain members - a triadic assessment of the influence of supply chain relationship quality on supply chain performance”, British Food Journal, Vol. 118 No. 7, pp. 1783-1799.

Olorunniwo, F. and Li, X. (2010), "Information sharing and collaboration practices in reverse logistics", Supply Chain Management: An International Journal, Vol. 15 No. 6, pp. 454-462.

Pfeffer, J. and Salancik, G.R. (1978), The External Control of Organizations - A Resource Dependence Perspective, Harper and Row Publishers, New York, NY.

Putnam, R. (1995), "Tuning in, tuning out: the strange disappearance of social capital in America", Political Science and Politics, Vol. 28 No. 4, pp. 664-687.

Reimann, F. and Ketchen, D.J. (2017), "Power in supply chain management", Journal of Supply Chain Management, Vol. 53 No. 2, pp. 3-9.

Roden, S. and Lawson, B. (2014), "Developing social capital in buyer-supplier relationships: the contingent effect of relationship-specific adaptations", International Journal of Production Economics, Vol. 151 No. C, pp. 89-99.

Sahin, F. and Robinson, E.P. (2002), "Flow coordination and information sharing in supply chains: review, implications, and directions for further research", Decision Sciences, Vol. 33 No. 4, pp. 505-536.

Sanchez, G., Trinchera, L. and Russolillo, G. (2017), Tools for Partial Least Squares Path Modeling (PLS-PM). R Package Version 0.4.9, available at: https://CRAN.R-project.org/package=plspm (accessed 15 May 2019).

Sanders, R.N. (2008), "Pattern of information technology use: the impact on buyer-supplier coordination and performance", Journal of Operations Management, Vol. 26 No. 3, pp. 349-367.

Schleper, M.C., Blome, C. and Wuttke, D.A. (2017), "The dark side of buyer power: supplier exploitation and the role of ethical climates", Journal of Business Ethics, Vol. 140, pp. 97-114.

Simsek, Z., Lubatkin, M.H. and Floyd, S.W. (2003), "Inter-firm networks and entrepreneurial behavior: a structural embeddedness perspective”, Journal of Management, Vol. 29, pp. 427-442.

Son, B., Kocabasoglu-Hillmer, C. and Roden, S. (2016), "A dyadic perspective on retailer-supplier relationships through the lens of social capital", International Journal of Production Economics, Vol. 178 No. 1, pp. 120-131.

Sufiyan, M., Haleem, A., Khan, S. and Khan, M.I. (2019), "Analysing attributes of food supply chain management: a comparative study", in Shanker, K., Shankar, R. and Sindhwani, R. (Eds), Advances in Industrial and Production Engineering, Springer, Singapore, pp. 515-523.

Tanner, A.N. and Strøm-Andersen, N. (2019), "Meat processing and animal by-products: industrial dynamics and institutional settings", in Klitkou, A., Fevolden, A.M. and Capasso, M. (Eds), 
BFJ 122,11

From Waste to Value: Valorisation Pathways for Organic Waste Streams in Circular Bioeconomies, Taylor and Francis, London.

Terpend, R., Tyler, B.B., Krause, D.R. and Handfield, R.B. (2008), "Buyer-supplier relationships: derived value over two decades", Journal of Purchasing and Supply Management, Vol. 44 No. 2, pp. 28-55.

Thakur, M. and Gunnlaugsson, V.N. (2018), "Information sharing strategies in whitefish supply chains in Norway vs. Iceland: impact on supply chain decision making", International Journal on Food System Dynamics, Vol. 9 No. 3, pp. 240-252.

Tran, T.T.H., Childerhouse, P. and Deakins, E. (2016), "Supply chain information sharing: challenges and risk mitigation strategies", Journal of Manufacturing Technology Management, Vol. 27 No. 8, pp. 1102-1126.

Uzzi, B. and Lancaster, R. (2003), "Relational embeddedness and learning: the case of bank loan managers and their clients", Management Science, Vol. 49 No. 4, pp. 383-399.

Van de Pas, B. (2019), Leading Meat Processers in the Netherlands in 2017, by revenue (in million U.S. dollars), available at: https:/www.statista.com/statistics/805123/.

Van den Hooff, B. and Huysman, M. (2009), "Managing knowledge sharing: emergent and engineering approaches", Information and Management, Vol. 46, pp. 1-8.

Vijayasarathy, L.R. (2010), "Supply integration: an investigation of its multi-dimensionality and relational antecedents", International Journal of Production Economics, Vol. 124 No. 2, pp. 489-505.

Villena, V., Revilla, E. and Choi, T. (2011), "The dark side of buyer-supplier relationships: a social capital perspective", Journal of Operations Management, Vol. 29 No. 1, pp. 561-576.

Wang, Z., Wang, N. and Liang, H. (2014), "Knowledge sharing, intellectual capital and firm performance”, Management Decision, Vol. 52 No. 2, pp. 230-258.

Whipple, J., Wiedmer, R. and Boyer, K. (2015), "A dyadic investigation of collaborative competence, social capital, and performance in buyer-supplier relationships", Journal of Supply Chain Management, Vol. 51 No. 2, pp. 3-21.

Wu, L. and Chiu, M.L. (2018), "Examining supply chain collaboration with determinants and performance impact: social capital, justice, and technology use perspectives", International Journal of Information Management, Vol. 39, pp. 5-19.

Wu, I., Chuang, C. and Hsu, C. (2014), "Information sharing and collaborative behaviors in enabling supply chain performance: a social exchange perspective", International Journal of Production Economics, Vol. 148 No. 1, pp. 122-132.

Yigitbasioglu, O.M. (2010), "Information sharing with key suppliers: a transaction cost theory perspective", International Journal of Physical Distribution and Logistics Management, Vol. 40 No. 7, pp. 550-578.

Yim, B. and Leem, B. (2013), "The effect of the supply chain social capital", Industrial Management and Data Systems, Vol. 113 No. 3, pp. 324-349.

Zhang, C. and Li, S. (2006), "Secure information sharing in internet-based supply chain management systems", The Journal of Computer Information Systems, Vol. 46 No. 4, pp. 18-24.

Zhou, H. and Benton, W. (2007), "Supply chain practice and information sharing", Journal of Operations Management, Vol. 25 No. 6, pp. 1348-1365.

\section{Further reading}

Flynn, B., Huo, B. and Zhao, X. (2010), "The impact of supply chain integration on performance: a contingency and configuration approach", Journal of Operations Management, Vol. 28 No. 1, pp. 58-71. 


\section{Appendix \\ Measurement of variables}

\begin{tabular}{|c|c|c|}
\hline Variable & Label & Items \\
\hline \multirow[t]{4}{*}{ Coercive power ${ }^{\mathrm{a}}$} & $\mathrm{CP} 1$ & $\begin{array}{l}\text { The major customer's personnel would somehow get back at us if we do not } \\
\text { make changes in our research and development }\end{array}$ \\
\hline & CP2R & $\begin{array}{l}\text { The major customer does not withdrawn certain needed services from us if } \\
\text { we do not make changes in our sales. }(\mathrm{R})\end{array}$ \\
\hline & CP3R & $\begin{array}{l}\text { The major customer does not hint that they would take certain actions if we } \\
\text { do not make changes in our production process. }(\mathrm{R})\end{array}$ \\
\hline & $\mathrm{CP} 4$ & $\begin{array}{l}\text { The major customer could have made things difficult for us if we do not } \\
\text { agree with their suggestions about distribution }\end{array}$ \\
\hline \multirow[t]{4}{*}{ Expert power ${ }^{\mathrm{a}}$} & $\mathrm{EP} 1$ & $\begin{array}{l}\text { Our major customer ensures changes in our research and development, } \\
\text { because we trust the customer's judgment }\end{array}$ \\
\hline & $\mathrm{EP} 2$ & $\begin{array}{l}\text { Our major customer ensures changes in our sales, because they have great } \\
\text { business expertise about sales }\end{array}$ \\
\hline & EP3R & $\begin{array}{l}\text { Our major customer does not ensure changes in our production, because we } \\
\text { usually do not have good advice from the customer. }(\mathrm{R})\end{array}$ \\
\hline & EP4 & $\begin{array}{l}\text { Our major customer ensures changes in our distribution, because they have } \\
\text { specially trained people who know what had to be done }\end{array}$ \\
\hline \multirow[t]{4}{*}{$\begin{array}{l}\text { Information } \\
\text { sharing }^{\mathrm{b}}\end{array}$} & IS1 & $\begin{array}{l}\text { We are willing to share information about the available stock with our major } \\
\text { customer }\end{array}$ \\
\hline & IS2 & We are willing to share our production planning with our major customer \\
\hline & IS3R & $\begin{array}{l}\text { We are not willing to share our production capacity with our major customer. } \\
\text { (R) }\end{array}$ \\
\hline & IS4R & We are not willing to share our actual sales data with our major customer. (R) \\
\hline \multirow[t]{5}{*}{$\begin{array}{l}\text { Relational social } \\
\text { capital }^{\text {b }}\end{array}$} & $\mathrm{RSC} 1$ & $\begin{array}{l}\text { Our major customer and we are concerned about the welfare or interests of } \\
\text { each other when making important decisions }\end{array}$ \\
\hline & $\mathrm{RSC} 2$ & $\begin{array}{l}\text { Our major customer and we are willing to offer assistance and support to } \\
\text { each other, even if the circumstance changes }\end{array}$ \\
\hline & $\mathrm{RSC} 3$ & Our major customer and we share confidential information with each other \\
\hline & $\mathrm{RSC} 4 \mathrm{R}$ & Our major customer and we do not have a close personal interaction. $(\mathrm{R})$ \\
\hline & RSC5 & $\begin{array}{l}\text { Our major customer and we are willing to invest in specific resources for } \\
\text { each other, because we maintain a close relationship }\end{array}$ \\
\hline \multirow[t]{3}{*}{$\begin{array}{l}\text { Structural social } \\
\text { capital }^{c}\end{array}$} & $\mathrm{SSC} 1$ & $\begin{array}{l}\text { Our major customer and we maintain close social relationships with each } \\
\text { other }\end{array}$ \\
\hline & $\mathrm{SSC} 2 \mathrm{R}$ & $\begin{array}{l}\text { Our major customer and we do not have frequent and intensive interaction } \\
\text { with each other. (R) }\end{array}$ \\
\hline & $\mathrm{SSC} 3 \mathrm{R}$ & $\begin{array}{l}\text { Our major customer and we did not obtain new interactions by the } \\
\text { cooperation. (R) }\end{array}$ \\
\hline \multirow{4}{*}{$\begin{array}{l}\text { Cognitive social } \\
\text { capital }^{\mathrm{d}}\end{array}$} & $\mathrm{CSC} 1$ & Our major customer and we share the same vision \\
\hline & CSC2R & Our major customer and we do not share the same ambitions. (R) \\
\hline & $\mathrm{CSC} 3$ & Our major customer and we share the same goals \\
\hline & CSC4R & $\begin{array}{l}\text { Our major customer is similar to us in that we both are willing to change for } \\
\text { the benefit of the relationship }\end{array}$ \\
\hline
\end{tabular}

Social capital, power and information sharing

3359

Note(s): (R) = recoded

${ }^{\text {a }}$ Brown et al. (1995), ${ }^{\mathrm{b}}$ Wu et al., (2014), Li et al. (2014), ${ }^{\mathrm{c}}$ Villena et al. (2011), ${ }^{\mathrm{d}} \mathrm{Li}$ et al. (2014), Son et al. (2016)

\section{About the authors}

Cees J. Gelderman, $\mathrm{PhD}$, is associate professor of Marketing and Purchasing Management at the Open University of the Netherlands. His research interests are in buyer-supplier relationships, public procurement and sustainability. Cees J. Gelderman is the corresponding author and can be contacted at: kees.gelderman@ou.nl 
BFJ

122,11

3360

Janjaap Semeijn, $\mathrm{PhD}$, is professor of Supply Chain Management at the Open University of the Netherlands with research interests in supply chain management, customer relationships, sustainability and logistics.

Ferdi Ter Avest, MSc, is supply chain manager at Offerman, a large Dutch producer and exporter of meat products and canned meat, Zwolle, the Netherlands.

Ellen Peeters, $\mathrm{PhD}$, is assistant professor of organizational psychology and human resources at the Open University of the Netherlands. Her research interest are: exit, dismissal, career transitions and change, employability, movement capital, human capital and optimal functioning of employees.

For instructions on how to order reprints of this article, please visit our website: www.emeraldgrouppublishing.com/licensing/reprints.htm Or contact us for further details: permissions@emeraldinsight.com 